DOI: http://dx.doi.org/10.18524/2307-4663.2018.3(43).142585

УДК 579.842.61: 616-092.4

T. V. Ivanytsia, I. V. Strashnova

Odesa National I. I. Mechnykov University,

2, Dvoryanska str, Odesa, 65082, Ukraine,

tel.: +38 (0482) 6879 64, e-mail: t.ivanytsia@gmail.com

\title{
QUANTITY AND BIOLOGICAL PROPERTIES OF THE BACTERIUM PANTOEA AGGLOMERANS ISOLATED FROM DIFERENT GRAPE VARIETIES IN ODESA REGION
}

\begin{abstract}
Aim. To isolate and investigate the biological properties of Pantoea agglomerans from the internal environment of grapes and tumors selected from the vineyards of the Odessa region. Methods. Samples of the grapevines of Arkadia, Moldova and Odessa souvenirs varieties and tumors cut from the affected veins and were presterilized, chopped into fragments, filled into a distilled water flask and stirred in a shaker at $28^{\circ} \mathrm{C}$ for 3 hours. It was made 10-times dilutions and cultured on the surface of Petrie's dishes with nutritients agar. Incubationon $28^{\circ} \mathrm{C}, 24-48$ hours. Conducted quantitative calculations, isolated pure cultures and examined their cultural, morphological, physiological and biochemical properties, determined the composition of cell lipids, and identified isolated strains. Antagonistic activity of P. agglomerans was determined by well-diffusion method. Results. Quantities of bacteria in inner part of grape fluctuated approximately 5,63 $\pm 1,3 \times 10^{3} \mathrm{CGU} /$ $\mathrm{SM}^{3}-2,96 \pm 1,3 \times 10^{5} \mathrm{CGU} / \mathrm{sM}^{3}$ and depended from time of the year and variety of grape. Quantities of microorganisms in tumors was bigger than in non damaged vine in the same period. Weight percentage P. agglomerans in vine fluctuated from $5.7 \%$ till $68.2 \%$, in tumors - from 9.88\% till 23.08\%. Strains of P. agglomerans isolated from endophytic medium of grape and tumor, characterized of similar morphological features. There were observed the ability to utilize carbohydrates, but in minnor. Pantoea strains did not consume sucrose from the tumors and $25.0 \%$ utilized raffinose in aerobic conditions, unlike strains from the intact vine. The fatty acid spectrum was represented by fatty acids containing 12 to 19 carbon atoms in the chain. Eighteen strains have been identified as P. agglomerans-GC subgroup A by fatty acid composition. For the strains examined, the dominant profiles are C16: 0, C12: 0, C14: 0, C17: 0 cyclo w7c. The isolated strains of $P$. agglomerans did not show antagonistic activity to the collection strains of E. carotovora, A. tumefaciens and A. vitis. Conclusions. The quantitative composition of the microbiota endophytic medium of the vine and the tumors was different and depended on the source of isolation, weather conditions and grape variety. The strains of P. agglomerans isolated from the vine and tumors were characterized by the same biological characteristics, with the exception of the ability to dispose of individual carbohydrates. Fatty acid composition of the investigated strains of Pantoea was represented by fatty acids with 12 to 19 carbon atoms in the chain. Antagonistic activity in the collection strains of E. carotovora, A. tumefaciens and A. vitis was not detected.
\end{abstract}

(C) Т. В. Іваниця, I. В. Страшнова, 2018 
Key words: Pantoea agglomerans, endophytic medium of grapevine and tumors, number, biological properties.

Pantoea agglomerans (Beijerinck 1888) comb. Nov [12] Earlier Enterobacteragglomerans (Beijerinck 1888) Ewing and Fife (1972), Erwinia herbicola (Löhnis 1911) Dye 1964, or Erwinia milletiae (Kawakami and Yoshida 1920) Magrou 1937, are gram-negative bacteria belonging to the Enterobacteriaceae family.

P. agglomerans, mainly, an epiphytic plant pathogen that develops on the surface of plants, or an endophyte that resides within plants [3, 19].

The widespread distribution of these bacteria in nature (they also occur in plant and animal products, in the body of animals, in water, soil, dust and air, and sometimes in humans) and their biological role in the different objects of existence are the subject of discussion and ambiguous relation to them. On the one hand, they can cause disorders in humans [18], can cause diseases of crops [8,9], and on the other hand, they produce substances that are effective in the treatment of cancer and other diseases of humans and animals, inhibit the development of various plant pathogens, promote the growth of plants and is a potentially effective biological fertilizer and biomediator $[7,10]$.

Since P. agglomerans characterizes the versatility of biology, ecology, and the role of the environment, scientific interest in them does not subsist. In view of this, the purpose of the work was to isolate and investigate the biological properties of Pantoea agglomerans from the endophytic medium of grapes and tumors selected from the vineyards of the Odessa region.

\section{Materials and methods}

In this work samples (stems) from the grapes "Arcadia", "Moldova" and "Odessa souvenir" were used, as well as tumors, and cut from the affected vine grapes of these varieties.

The preparation of all samples was unified and consisted of the following stages. Samples of the grapevine and the tumors were preliminarily soaked under running water, washed with sterile distilled water, and sterilized the surface, treating $96{ }^{\circ} \mathrm{C}$ with alcohol and flaming.

After this, maintaining sterile conditions, the selected samples were chopped into fragments approximately $0.5 \mathrm{~cm}$ in size, $10 \mathrm{~g}$ of which were transferred to conical flasks of $250 \mathrm{~cm}^{3}$ and placed on $50 \mathrm{~cm}^{3}$ of sterile distilled water for each sample. Experimental samples were mixed in a shaker (from New Brunswick at $250 \mathrm{RPM}$ ) at $28^{\circ} \mathrm{C}$ for $3 \mathrm{~h}$. After that, a series of 10 consecutive dilutions was made. Petri dishes with nutrient agar (Merck, Germany) were cultured on the surface of $0.1 \mathrm{~cm}^{3}$ of appropriate dilutions. The seeds were incubated at $28^{\circ} \mathrm{C}$ for $24-48$ hours.

It was calculated a quantitative of microorganisms that grew up, isolated pure cultures and investigated biological properties: cultural, morphological, physiological and biochemical.

For the analysis of cell lipids composition, samples were prepared with bacterial cultures which were pre-incubated at Tryptic soy agar (Merck, Germany) at a temperature of $28 \pm 1^{\circ} \mathrm{C}$ for 24 hours. 
Three full loops of biomass were placed in the reaction vial and a concentrated $\mathrm{NaOH}$ solution was added. This samples was thoroughly mixed and placed on a water bath and maintained at $95-100{ }^{\circ} \mathrm{C}$ for 5 minutes. After that, the mixing was repeated and left in a water bath at $95-100^{\circ} \mathrm{C}$ for 25 minutes to completely destroy the bacterial cells and purify the lipids. To the cooled suspension, a solution of acidified methanol was added and held in a water bath at $80{ }^{\circ} \mathrm{C}$ for 10 minutes to obtain the fatty acid methyl esters, which were then extracted with hexane. The extract was neutralized with $0.3 \mathrm{M}$ alkaline solution and analyzed by gas chromatography [1].

The chromatographic separation of methyl esters of LC was performed on a gas chromatograph Agilent 7890 (Agilent Technologies, USA) with a capillary column ULTRA 2 and a semi-ionization detector. Samples of $2 \mu \mathrm{l}$ were injected into the evaporator in a split mode with a coefficient of 40:1, temperature of evaporator $250{ }^{\circ} \mathrm{C}$. The separation was carried out in the programming mode of temperature - the initial temperature $170{ }^{\circ} \mathrm{C}$ with a gradient of $5{ }^{\circ} \mathrm{C} / \min$ to $270{ }^{\circ} \mathrm{C}$. The fatty acids content was expressed as a percentage of the total sum of peak areas.

MIDI Sherlock 4.5 software and the RSTBA6 version 6.21 fatty acid profile of the aerobic microorganisms were used to identify the strains examined for their fatty acid profile.

The antagonistic activity of the strains of $P$. agglomerans to the collection strains of Erwinia carotovora, Agrobacterium tumefaciens and Agrobacterium vitis, as well as intrinsic antagonism were determined by the hole diffusion method, measuring the growth test inhibition zones of the test strains after 24 hours of cultivation at $28^{\circ} \mathrm{C}[2]$.

Statistical processing of the results of the study was carried out using the MS Excel computer program with the definition of Student's $t$-criterion. The difference was statistically significant at $\mathrm{P}<0.05$.

\section{Results and discussion}

The internal environment of the vine grape contains a significant number of bacteria that influence on the lasting of physiological processes in plants, promote the protection of plants against pathogens, but some, under certain conditions, can cause disease or influence on the infectious process. These bacteria include P. agglomerans, which can be used as an indicator of yeast and mold (mold) fungal biocontrol, pathogenic bacteria, but it can itself be an opportunistic pathogen.

Experimental studies were carried out in April-October 2017. Depending on the month of the research and the grape variety, the number of microorganisms of the internal environment of the grapes varied within the limits of $5.63 \pm 1.3 \mathrm{~ms} 10^{3}$ $\mathrm{CFU} / \mathrm{cm}^{3}-2.96 \pm 1.3 \mathrm{~ms} 10^{5} \mathrm{CFU} / \mathrm{cm}^{3}$.

The smallest number of microbiota was detected in April, the largest in September 2017, due to weather seasonal and climatic conditions.

In September and October, defects in the form of tumors were detected on grape barrels of all varieties, in the internal environment the total number of microbiota was higher in September (Fig. 1).

The obtained results indicate the sensitivity of these bacteria to weather conditions. The frequency of isolation of $P$. agglomerans was bigger in September 
2017 (for sufficiently dry weather and moderate summer temperature, $28-30{ }^{\circ} \mathrm{C}$ ), the smallest - in October of this year (when in the beginning of the month there was a significant decrease in temperature, $12-15^{\circ} \mathrm{C}$ ).

In addition to $P$. agglomerans, other microorganisms were isolated from the endophytic medium of grapes, most of which were representatives of the genera Agrobacterium and Erwinia.

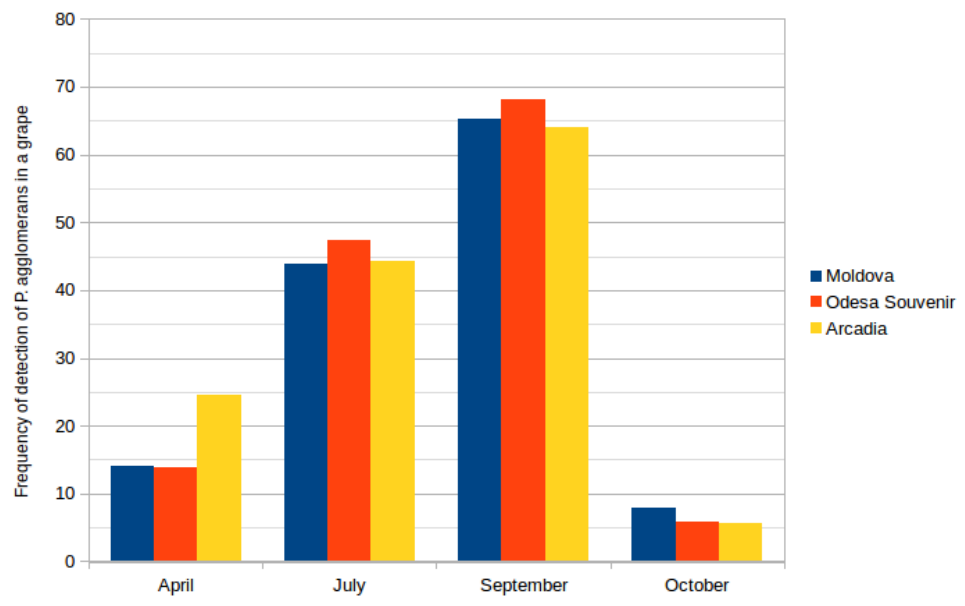

Fig. 1. Frequency of detection of bacteria $P$. agglomerans in a grape, 2017 year (data presented in percentages)

P. agglomerans were also isolated from the internal environment of the tumors. The percantage of them among the other microbiota was higher in October and amounted to slightly more than $20.0 \%$, in September this figure was two times smaller (Figure 2).

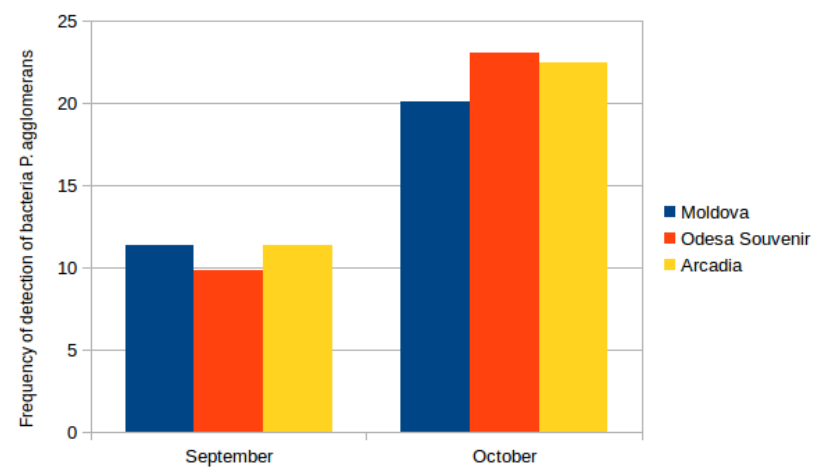

Fig. 2. Frequency of detection of bacteria $P$. agglomerans in a grape's tumor in 2017 year

Comparing the obtained data shown in Fig. 1 and 2, it should be noted that in September in the endophytic environment of the intact grapevine all varieties were dominated by P. agglomerans, whereas in tumors their proportion was much 
smaller. In October, in the grapevine, the proportion of $P$. agglomerans decreased significantly, while in tumors, on the contrary, it increased. The taxonomic composition of the bacteria isolated from the tumors was more varied than in the grapevine. Among the isolates, bacteria of the genus Agrobacterium, Erwinia, Xanthomonas, Achromobacter, Serratia predominated.

Compare obtained results and data with literary sources [10, 18], it was supposed that bacteria $P$. agglomerans could be as representative in both sides, of normal microbiota of grapes and one of the potential pathogens involved in the formation of tumors.

Biological properties have shown that isolated and selected samples were coinciding with the characteristics of bacteria $P$. agglomerans. All strains of $P$. agglomerans were able to grow on nutrient agar; forming in 24 hours at $28{ }^{\circ} \mathrm{C}$ rounded, smooth, regular, carved, shiny, translucent colonies; capable for pigmentation of bright yellow color; with sizes of $0.5-3 \mathrm{~mm}$.

A microscopic study has shown that isolated bacteria are gram-negative, the rod-shaped, with rounded ends. The cell sizes are defined within the range of 0.5 $-1.0 \times 1-3 \mu \mathrm{m}$. Bacteria are capable to movement.Also, the optimal growth temperature was observed in the range of $25-30{ }^{\circ} \mathrm{C}$, and it is typical for these bacteria.

All strains are oxidase-negative and catalase-positive. The ability to utilize carbohydrates was different in strains isolated from intact grapevine and from tumors (Table 1).

All tested strains were utilized only with the release of maltose, mannose, mannitol, xylose, rhamnose in aerobic and anaerobic conditions, and lactose only in anaerobic conditions. Pantoea strains isolated from tumors did not consume sucrose and $25.0 \%$ utilized raffinose in aerobic conditions, unlike strains from intact grapevines.

For the Pantoea agglomerans strains the presence of isomers of fatty acids with a carbon chain length of 12 to 19 carbon atoms were shown. Among the saturated isomers, hexadecanoic acid (C16:0) was dominant with a total content of 29.1 to $30.83 \%$ of the total sum of peak areas. The content of tetradecanoic acid (C14:0) ranged from 4.78 to $5.72 \%$, dodecan (C12:0) - from 3.04 to $4.57 \%$, octadecanoic acid - from 0.24 to $0.37 \%$. The content of saturated isomers with an odd number of carbon atoms: tridecan $(\mathrm{C} 13: 0)$, heptadecan $(\mathrm{C} 17: 0)$ was within the range of no more than 0.14 and $0.34 \%$, respectively. For all studied strains, a high content of cycloheptadecanoic acid (cyclo-C17:0) was characterized from 3.74 to $7.55 \%$ of the total sum of peak areas. For strains $1 \mathrm{a}$ and 4 , the presence of pentadecanoic fatty acid $(\mathrm{C} 15: 0)$ in the amount less than $0.1 \%$ is shown. For these strains, the presence of both 13-methyl-pentadecane (iso) and 12-methyl-pentadecane (anteiso) isomers was characteristed. The presence of cyclo-nonadecanoic acid (cyclo-C19:0) in trace amounts for most strains has been shown.

For the fatty acid composition of all investigated strains of Pantoea agglomerans, the dominance of a mixture of isomers of hexadecenic acid (C16:1) was characteristic, the content of which ranged from 30.33 to $36.92 \%$. The presence of isomers with unsaturated bonds in the 9,10 , and 11 positions of the carbon chain is shown. Dominant were 9-hexadecenic (9-C16:1) and 10-hexadecenic 
Biochemical activity of Pantoea strains isolated from grape and tumors

\begin{tabular}{|c|c|c|c|}
\hline \multirow{2}{*}{\multicolumn{2}{|c|}{ Carbons }} & \multicolumn{2}{|c|}{ Strains, isolated from } \\
\hline & & Vinegrape & Tumors \\
\hline \multirow{2}{*}{ Maltose } & Aerobic conditions & + & + \\
\hline & Anaerobic conditions & + & + \\
\hline \multirow{2}{*}{ Mannose } & Aerobic conditions & + & + \\
\hline & Anaerobic conditions & + & + \\
\hline \multirow{2}{*}{ Mannitol } & Aerobic conditions & + & + \\
\hline & Anaerobic conditions & + & + \\
\hline \multirow{2}{*}{ Xylose } & Aerobic conditions & + & + \\
\hline & Anaerobic conditions & + & + \\
\hline \multirow{2}{*}{ Rhamnose } & Aerobic conditions & + & + \\
\hline & Anaerobic conditions & + & + \\
\hline \multirow{2}{*}{ Glucose } & Aerobic conditions & + & + \\
\hline & Anaerobic conditions & + & + \\
\hline \multirow{2}{*}{ Lactose } & Aerobic conditions & - & - \\
\hline & Anaerobic conditions & + & + \\
\hline \multirow{2}{*}{ Sucrose } & Aerobic conditions & + & - \\
\hline & Anaerobic conditions & + & + \\
\hline \multirow{2}{*}{ Raffinose } & Aerobic conditions & - & {$[-]$} \\
\hline & Anaerobic conditions & + & + \\
\hline
\end{tabular}

Note: "+" - positive characteristic; «-» - negative characteristic; "[-]" - positive characteristic in $25.0 \%$ strain.

(10-C16:1) isomers. Among the unsaturated isomers for all investigated strains, 11-octadecenoic fatty acid (11-C18:1) was characterized by a content of 10.43 to $14.0 \%$. 13-Oktadecenic acid was detected in trace amounts in strains $1 \mathrm{a}, 3,9,15$, $22 x, 24,25,27$.

For all investigated strains, the presence of hydroxylated fatty acids was characteristed. Thus, the content of 3-hydroxy-tetradecanoic acid (3-OH-C14: 0) ranged from 6.22 to $9.98 \%$ of the total sum of peak areas. The content of 2 -hydroxydodecanoic acid was observed at a level less than $0.1 \%$ for strains $1 \mathrm{a}, 4,15,22 \mathrm{x}$, 24, 25 and 27. For strains 35, 36, 41 and 41a, the presence of a small amount of 3-hydroxy-pentadecane acids (3-OH-C15:0) - less than 0,2\% was shown.

For strains 35, 36, 41 and 41a, a small amount of 3-hydroxy-pentadecanoic acid (3-OH-C15:0) is shown to be less than $0.2 \%$. For strains 35 and $41 \mathrm{a}$, the presence of 2-hydroxy-pentadecanoic acid (2-OH-C15:0) in the amount of 0.33 and $0.4 \%$, (Table 2 ), respectively, is shown.

The genus Pantoea was first described by Gavini [12] with the sole representatives of the species Pantoea agglomerans. To date, this genus has 22 validated and described species, among which Pantoea allii, Pantoea brenneri, 
Pantoea calida, Pantoea coffeiphila, Pantoea conspicua, Pantoea intestinalis, Pantoea rodasii, Pantoea rwandensis, Pantoea theicola, Pantoea alhagi, recently posted.

Representatives of the genus Pantoea belong to the Enterobacteriacea family. One of the chemotaxonomic markers of this group is the presence of hydroxy acids in the structure of the lipopolysaccharides. The lipopolysaccharides are the main component of the external membrane of the cellular wall of gram-negative bacteria, which plays a key role in interaction of the cell with surrounding objects. Thus, in the purified lipopolysaccharides of the strain Pantoea agglomerans 7969 3-hydroxytradecanoic acid, dodecanova, tetradecanova, hexadecan and 2-hydroxytetradecanova were detected.

The total fatty acid composition of the typical Pantoea agglomerans LMG $1286 \mathrm{~T}$ cells includes typical dodecanic, tetradecanoic, hexadecanoic, cycloheptadecanoic fatty acids in the amount of $3.8 ; 6 ; 27.1 ; 13.2 \%$ of the total sum of peak areas [16]. A characteristic feature is the high content of hexadecenoic and octadecenoic fatty acids -24.2 and $11.6 \%$, respectively. The content of 3 -hydroxytradecanoic acid is $6 \%$. Brady et al. characterized three new species of the Pantoea family that cause bacterial blight and dieback of eucalyptus in Colombia - Pantoea rodasii, Rwanda - Pantoea rwandensis and South Africa Pantoea wallisii $[5,4,6]$. All isolates were characterized by a typical set of fatty acids of representatives of Pantoea. Strains Pantoea rodasii, Pantoea rwandensis had a close spectrum (Table 2). Pantoea wallisii had differs from the two previous slightly higher content of octadecenoic fatty acid $-18.8 \%$, and decrease in the proportion of hexadecenoic $16.3 \%$ and tetradecanoic acid 3.5\%.

Fatty acid composition of the representatives of the genus Pantoea has a typical set of fatty acids. It is characterized by high content of unsaturated isomers - hexa- and octadecenoic acids, saturated dodecanoic, tetradecanoic, hexadecanoic, cycloheptadecanoic fatty acids. The presence of hydroxylated isomers at least 3 -hydroxydodecanoic is compulsory.

In the investigated isolates, the presence of all characteristic isomers with contents close to those described in the literature of isolates is shown (Table 3).

High similarity indices obtained when identifying investigated isolates using the automated identification system of MIDI Sherlock microorganisms allow us to conclude that they belong to the Pantoea family.

Also considering that the cause of some infectious diseases of the grapes is the bacteria of the genera Erwinia and Agrobacterium, and it was they who dominated in the internal environment of the vines and tumors, the ability of the isolated P. agglomerans strains to suppress the growth of the collection strains of E. carotovora (12 strains), A. tumefaciens ( 2 strains) and A. vitis ( 1 strain) was investigated. It was found that none of the investigated collection strains of phytopathogenic bacteria shown sensitivity to the metabolites of strains P. agglomerans.

Thus, studies have shown that the quantitative composition of the endophytic microbiota of the intact vine and tumors varied depending on the weather conditions and the grape variety, while in the tumors the number of bacteria was higher. The frequency isolation bacteria of the genus Pantoea was determined by the medium of selection and weather conditions and did not depend on the grape variety. The 
$\frac{N}{\frac{0}{0}}$

\begin{tabular}{|c|c|c|c|c|c|c|c|c|c|c|c|c|c|c|c|c|c|}
\hline$\frac{\pi}{7}$ & $\frac{\simeq}{\underset{\forall}{J}}$ & 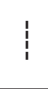 & 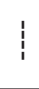 & $\begin{array}{l}\mathcal{Y} \\
i\end{array}$ & 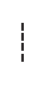 & 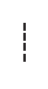 & $\frac{ \pm}{a}$ & 6 & $\frac{\infty}{0}$ & ָे & $\underset{\tau}{\nabla}$ & $\stackrel{\nabla}{0}$ & $\frac{a}{0}$ & $\stackrel{m}{0}$ & $\begin{array}{l}\mathbb{J} \\
\dot{i}\end{array}$ & $\stackrel{?}{\circ}$ & $=$ \\
\hline$F$ & 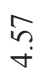 & $\frac{ \pm}{0}$ & 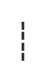 & $\underset{i n}{\stackrel{N}{i}}$ & 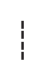 & $\stackrel{1}{\circ}$ & $\begin{array}{l}\infty \\
\stackrel{a}{\alpha}\end{array}$ & & $\overrightarrow{0}$ & 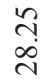 & กै & $!$ & 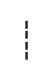 & 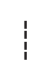 & $n$ & $\stackrel{+}{\circ}$ & \\
\hline లి & $\stackrel{\infty}{\circ}$ & 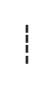 & 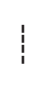 & $\begin{array}{l}b \\
i n\end{array}$ & 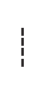 & $\frac{1}{0}$ & $\begin{array}{l}+ \\
\infty \\
\infty\end{array}$ & & $\overrightarrow{0}$ & $\begin{array}{l}\text { D. } \\
0 \\
0\end{array}$ & $\stackrel{\circ}{-2}$ & 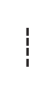 & 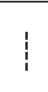 & 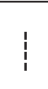 & & ़ֻ & 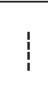 \\
\hline$\tilde{m}$ & $\begin{array}{l}\text { ळे } \\
\text { ஸे }\end{array}$ & 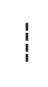 & 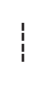 & $\begin{array}{l}\bar{n} \\
i n\end{array}$ & 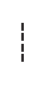 & 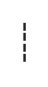 & ?a & ? & $\overrightarrow{0}$ & $\begin{array}{l}\infty \\
\grave{\lambda}\end{array}$ & 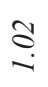 & $\stackrel{m}{n}$ & 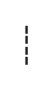 & 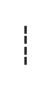 & $\hat{\hat{n}}$ & 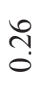 & 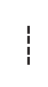 \\
\hline$\hat{\sim}$ & $\overrightarrow{c r}$ & $\begin{array}{l}\circ \\
\stackrel{0}{0}\end{array}$ & $\stackrel{t}{\circ}$ & $\begin{array}{l}\exists \\
\ddot{n}\end{array}$ & 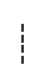 & 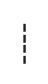 & $\stackrel{+}{n}$ & $\approx$ & $\frac{m}{0}$ & $\begin{array}{l}0 \\
\stackrel{0}{0} \\
\stackrel{0}{0}\end{array}$ & 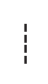 & 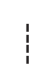 & 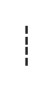 & $\stackrel{n}{\circ}$ & & 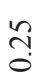 & $\stackrel{n}{0}$ \\
\hline $\mathscr{N}$ & $m$ & $\stackrel{0}{0}$ & $\stackrel{+}{0}$ & ִָ & 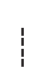 & 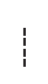 & $\stackrel{\bar{n}}{r}$ & 7 & $\stackrel{n}{\circ}$ & $\begin{array}{l}\stackrel{n}{\sigma} \\
\stackrel{\sim}{\alpha}\end{array}$ & 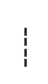 & 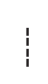 & 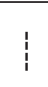 & $\begin{array}{l}0 \\
0\end{array}$ & $m$ & ઼ָ & $\stackrel{n}{0}$ \\
\hline$\stackrel{\sim}{\sim}$ & $\underset{\sim}{\stackrel{t}{~}}$ & $\stackrel{\leftrightarrow}{\circ}$ & $\stackrel{n}{\circ}$ & $\underset{\sim}{\stackrel{\infty}{\sim}}$ & 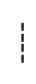 & 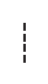 & $\frac{n}{\pi}$ & $\bar{a}$ & $\frac{ \pm}{0}$ & \begin{tabular}{l}
$\circ$ \\
$\stackrel{\text { \} }{ }}$ & 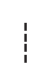 & 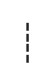 & 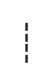 & $\stackrel{\leftrightarrow}{\circ}$ & & $\begin{array}{l}\text { ָे } \\
\text { ஸे }\end{array}$ & $\stackrel{n}{0}$ \\
\hline$\underset{\sim}{\sim}$ & $\frac{9}{m}$ & $\stackrel{2}{2}$ & 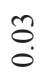 & $\begin{array}{l}\text { to. } \\
\text { in }\end{array}$ & 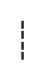 & 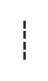 & $\stackrel{\sim}{\sim}$ & 7 & $\stackrel{1}{0}$ & $\frac{\vec{n}}{n}$ & 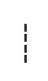 & 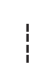 & 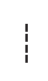 & $\underset{0}{\stackrel{0}{0}}$ & $\begin{array}{l}\infty \\
\dot{+}\end{array}$ & ֶֻ. & $\stackrel{2}{0}$ \\
\hline$\cong$ & $\underset{m}{\infty}$ & $\stackrel{0}{0}$ & $\stackrel{+}{0}$ & $\hat{n}$ & 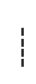 & 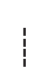 & $\sqrt{n}$ & $\alpha$ & $\stackrel{1}{0}$ & $\hat{a}$ & 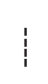 & 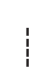 & 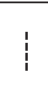 & $\stackrel{n}{\circ}$ & $\begin{array}{l}\stackrel{\odot}{+}\end{array}$ & $\stackrel{?}{0}$ & $\stackrel{0}{0}$ \\
\hline $\mathcal{I}$ & $\stackrel{n}{n}$ & 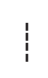 & 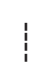 & $\frac{n}{n}$ & 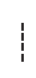 & 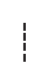 & 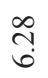 & & $\frac{ \pm}{0}$ & $\begin{array}{l}n \\
2 \\
2\end{array}$ & 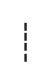 & 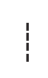 & 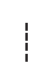 & 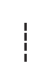 & $\stackrel{N}{\mathcal{T}}$ & $\frac{\infty}{0}$ & 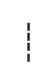 \\
\hline$\varrho$ & $\underset{c}{~}$ & 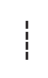 & 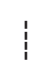 & 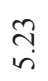 & 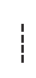 & 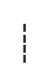 & ?ु? & - & $\stackrel{m}{\circ}$ & $\begin{array}{l}\text { : } \\
\dot{0}\end{array}$ & 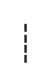 & 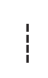 & 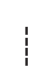 & 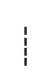 & $\begin{array}{l}\hat{\sigma} \\
\dot{\gamma}\end{array}$ & $\frac{1}{0}$ & 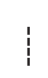 \\
\hline$a$ & $\bar{c}$ & $\stackrel{n}{0}$ & 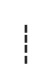 & $\vec{m}$ & 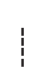 & 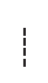 & તี & $\checkmark$ & $\frac{m}{0}$ & 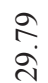 & 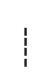 & 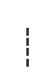 & 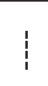 & 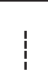 & กี & $\vec{\jmath}$ & 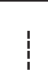 \\
\hline$r$ & $\stackrel{5}{n}$ & 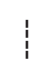 & 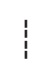 & $\stackrel{\infty}{\stackrel{\infty}{+}}$ & 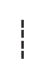 & 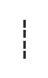 & $\underset{\infty}{ \pm}$ & $\overrightarrow{0}$ & $\frac{m}{0}$ & $\begin{array}{l}\overrightarrow{+} \\
\infty \\
\sim\end{array}$ & 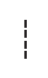 & 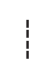 & 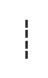 & 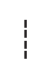 & $\hat{n}$ & $\begin{array}{l}\text { ָ̦ } \\
\text { a }\end{array}$ & 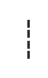 \\
\hline$n$ & $\stackrel{\alpha}{\alpha}$ & ô. & 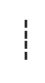 & $\stackrel{\nabla}{\stackrel{\nabla}{+}}$ & 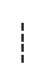 & 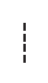 & $\frac{m}{b}$ & & $\frac{m}{0}$ & $\stackrel{\overbrace{}}{\stackrel{\sim}{2}}$ & 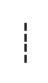 & 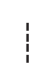 & 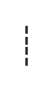 & 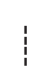 & m & $\stackrel{m}{m}$ & 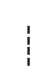 \\
\hline$\nabla$ & $m$ & $\stackrel{\infty}{\circ}$ & $\stackrel{n}{2}$ & $\frac{m}{n}$ & $\widetilde{0}$ & $\underset{0}{\circ}$ & f̊? & & \pm & $\begin{array}{l}\text { n? } \\
\grave{2}\end{array}$ & 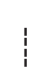 & 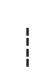 & 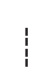 & $\begin{array}{l}2 \\
0\end{array}$ & & $\vec{m}$ & 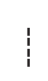 \\
\hline n & $\underset{\text { రె }}{\tilde{r}}$ & $\overrightarrow{0}$ & 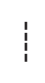 & $\stackrel{\infty}{+}$ & 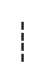 & 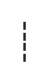 & $\frac{0}{\sigma 0}$ & $\begin{array}{l}\stackrel{g}{c} \\
\text { m }\end{array}$ & $\stackrel{m}{0}$ & $\overrightarrow{\mathrm{d}}$ & 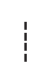 & 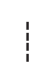 & 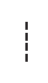 & ல̊. & $n$ & $\stackrel{\infty}{\stackrel{\infty}{0}}$ & $\begin{array}{l}0 \\
\circ\end{array}$ \\
\hline 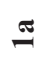 & c & $\stackrel{n}{o}$ & $\stackrel{\Xi}{0}$ & $\underset{r}{\stackrel{\vartheta}{r}}$ & $\stackrel{\hat{o}}{0}$ & $\stackrel{\circ}{\circ}$ & $\frac{n}{\pi}$ & $\mathrm{c}$ & $\frac{1}{0}$ & 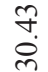 & 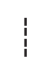 & 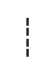 & 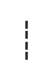 & $\begin{array}{l}\stackrel{2}{0} \\
0\end{array}$ & $\dot{\nabla}$ & 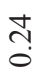 & $\begin{array}{l}\circ \\
0 \\
0\end{array}$ \\
\hline- & $\underset{n}{\stackrel{N}{r}}$ & $\begin{array}{l}0 \\
\stackrel{0}{0}\end{array}$ & 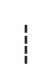 & $\begin{array}{l}\bar{n} \\
n\end{array}$ & $\mid$ & 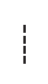 & $\vec{\infty}$ & y & $\stackrel{ \pm}{\overrightarrow{0}}$ & $\begin{array}{l}n \\
\text { nे }\end{array}$ & 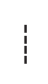 & 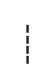 & 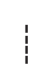 & 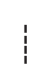 & $n$ & $\frac{9}{0}$ & ! \\
\hline 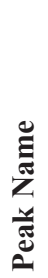 & 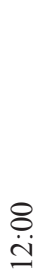 & $\begin{array}{l}8 \\
\dot{\varphi}\end{array}$ & $\begin{array}{l}\mathbb{I} \\
0 \\
m \\
0 \\
\dot{\mathrm{d}}\end{array}$ & $\begin{array}{l}\stackrel{8}{\dot{ \pm}} \\
\dot{\dot{ \pm}}\end{array}$ & 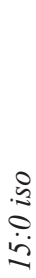 & 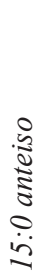 & $\begin{array}{l}\frac{T}{0} \\
\text { లn } \\
\stackrel{0}{ \pm} \\
\dot{\dot{J}}\end{array}$ & $\frac{\overrightarrow{6}}{\frac{1}{3}}$ & $\begin{array}{l}\ddot{n} \\
\vdots \\
\ddot{6}\end{array}$ & $\underset{ْ}{8}$ & 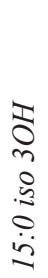 & 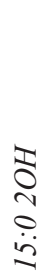 & 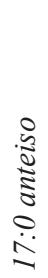 & $\begin{array}{l}\infty \\
\vdots \\
\\
\end{array}$ & $\begin{array}{l}0 \\
0 \\
0\end{array}$ & $\begin{array}{l}8 \\
\stackrel{1}{-}\end{array}$ & 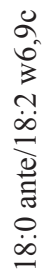 \\
\hline
\end{tabular}
\end{tabular}




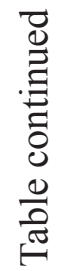

\begin{tabular}{|c|c|c|c|c|}
\hline $\begin{array}{l}\infty \\
\infty \\
\stackrel{0}{0}\end{array}$ & 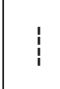 & 志 & $\stackrel{7}{\circ}$ & $\stackrel{+}{\stackrel{0}{0}}$ \\
\hline$\stackrel{?}{\stackrel{9}{\ominus}}$ & 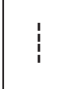 & ป̀ & $\stackrel{7}{0}$ & 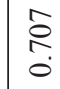 \\
\hline $\begin{array}{l}\text { ț } \\
\stackrel{0}{0}\end{array}$ & 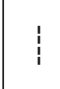 & 官 & $\frac{m}{0}$ & 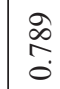 \\
\hline$\stackrel{n}{=}$ & 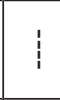 & $\begin{array}{l} \\
\text { Iִ } \\
\end{array}$ & $\overline{0}$ & $\begin{array}{c}\mathcal{D} \\
\infty \\
0\end{array}$ \\
\hline $\begin{array}{c}0 \\
\stackrel{-}{\mathrm{I}}\end{array}$ & $\begin{array}{l}0 \\
0 \\
0\end{array}$ & 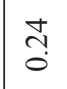 & $\begin{array}{l}\infty \\
0 \\
0\end{array}$ & $\begin{array}{l}\tilde{N} \\
\infty \\
0\end{array}$ \\
\hline$\vec{\sigma}$ & $\begin{array}{l}0 \\
0 \\
0\end{array}$ & $\overrightarrow{\widetilde{\sigma}}$ & $\overrightarrow{0}$ & $\begin{array}{l}\hat{0} \\
0\end{array}$ \\
\hline \pm & I & さ্ড & $\begin{array}{l}\infty \\
0 \\
0\end{array}$ & $\begin{array}{l}\bar{n} \\
\stackrel{0}{0}\end{array}$ \\
\hline 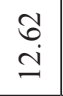 & t. & ڤn & $\begin{array}{l}\infty \\
0 \\
0\end{array}$ & $\begin{array}{l}\tilde{2} \\
0 \\
0 \\
0\end{array}$ \\
\hline $\begin{array}{l}\infty \\
n \\
n \\
\end{array}$ & $\begin{array}{l}0 \\
0 \\
0\end{array}$ & $\hat{\tilde{O}}$ & Oे. & \begin{tabular}{l} 
f \\
\multirow{0}{*}{} \\
0
\end{tabular} \\
\hline $\begin{array}{l}\vec{\partial} \\
\dot{g}\end{array}$ & 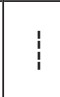 & $\overrightarrow{\widetilde{\sigma}}$ & $\overrightarrow{0}$ & $\begin{array}{l}\overrightarrow{8} \\
0\end{array}$ \\
\hline $\begin{array}{l}\overrightarrow{\mathrm{N}} \\
\stackrel{-}{ }\end{array}$ & 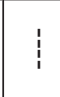 & ปั & ó & 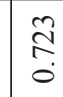 \\
\hline 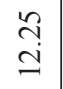 & $\begin{array}{l}n \\
0 \\
0\end{array}$ & $\stackrel{\text { ț }}{\text { s. }}$ & $\stackrel{0}{0}$ & 究 \\
\hline $\begin{array}{l}\tilde{O} \\
\stackrel{g}{-}\end{array}$ & 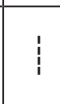 & $\stackrel{n}{0}$ & 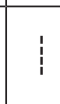 & $\begin{array}{l}\stackrel{\infty}{?} \\
\stackrel{0}{0}\end{array}$ \\
\hline $\begin{array}{l}\vec{\exists} \\
\dot{ \pm}\end{array}$ & 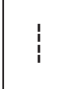 & స్ & 7 & $\begin{array}{l}\stackrel{n}{\infty} \\
0 \\
0\end{array}$ \\
\hline $\begin{array}{l}\hat{m} \\
\vec{n}\end{array}$ & 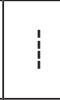 & $\begin{array}{l}2 \\
0 \\
0\end{array}$ & $\overrightarrow{0}$ & $\begin{array}{l}0 \\
0 \\
0\end{array}$ \\
\hline $\begin{array}{l}\curvearrowleft \\
\alpha \\
\dot{ \pm}\end{array}$ & $\begin{array}{l}n \\
0 \\
0\end{array}$ & ते & $\stackrel{2}{0}$ & $\begin{array}{l}\text { I } \\
\text { Oे }\end{array}$ \\
\hline 3 & 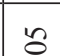 & $m$ & - & 80 \\
\hline
\end{tabular}

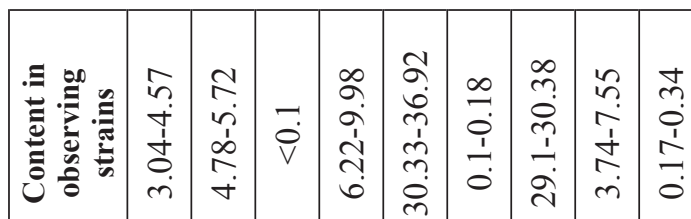

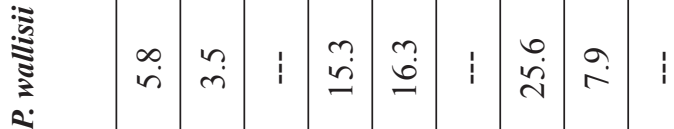

בิ

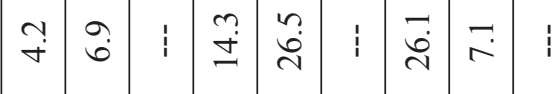

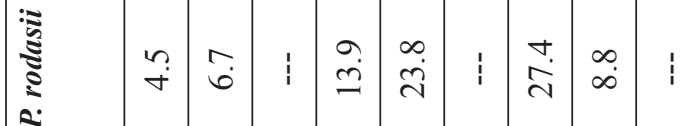

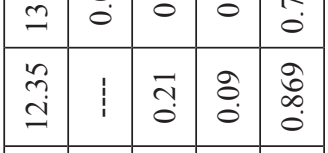

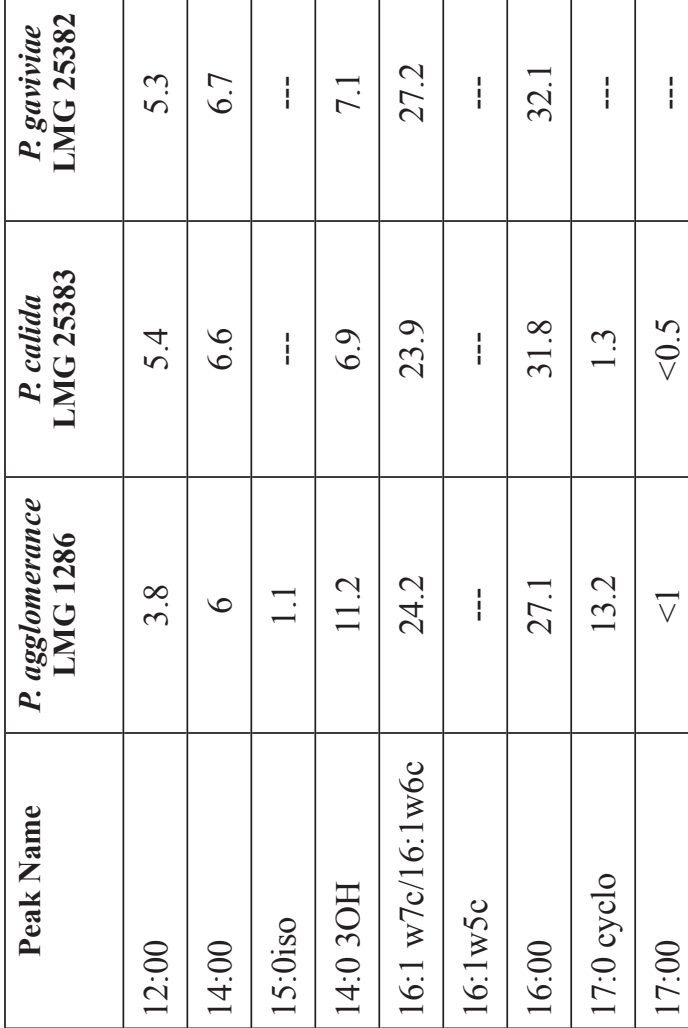

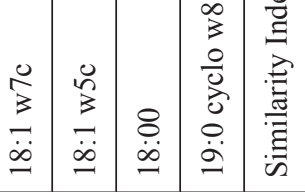


biological properties of the $P$. agglomerans strains isolated from the veins and tumors were the same except of the ability to utilize individual carbohydrates. Allocated strains are not capable to suppress the growth of collection strains of phytopathogenic bacteria.

T. В. Іваниця, I. В. Страшнова

Одеський національний університет імені I. І. Мечникова, вул. Дворянська, 2, Одеса, 65082, Україна, тел.: +38 (0482) 6879 64, e-mail: t.ivanytsia@gmail.com

\title{
ЧИСЕЛЬНІСТЬ І БІОЛОГІЧНІ ВЛАСТИВОСТІ БАКТЕРІЙ РАNTOEА AGGLOMERANS, ВИДІЛЕНИХ З РІЗНИХ СОРТІВ ВИНОГРАДУ ОДЕСЫКОЇ ОБЛАСТІ
}

\begin{abstract}
Реферат
Мета. Ізолювати і дослідити біологічні властивості Pantoea agglomerans із внутрішнього середовища виноградної лози і пухлин виноградної лози, відібраних з виноградників Одеської області. Методи. Зразки виноградної лози сортів «Аркадія», «Молдова» $i$ «Одеський сувенір» $і$ пухлин, зрізаних з ураженої лози ичих сортів, попередньо стерилізували фламбуванням, подрібнювали на фрагменти, вносили їх у колби з дистильованою водою $і$ перемішували в шейк ері при $28^{\circ} \mathrm{C}$ протягом 3 год. Робили серію 10-ти кратних послідовних розведень $і$ висівали на поверхню чашок Петрі з поживним агаром. Інкубували при $28{ }^{\circ} \mathrm{C}$ протягом 24-48 год. Проводили кількісний облік, виділяли чисті культури і досліджували їх культуральні, морфологічні, фізіолого-біохімічні властивості, визначали склад клітинних ліпідів та проводили ідентифікацію виділених штамів. Антагоністичну активність P. agglomerans визначали лунково-дифузійним методом. Результати. Чисельність бактерій у внутрішньому середовищі винограду коливалася у межах 5,63 $\pm 1,3 \times 10^{3} \mathrm{KУO} / \mathrm{cm}^{3}-2,96 \pm 1,3 \times 10^{5} \mathrm{KУO} / \mathrm{cm}^{3}$ i залежала від пори року і сорту винограду. Кількість мікроорганізмів у пухлинах була більшою ніж в неушкодженій лозі у той же період. Масова частка P. agglomerans y лозі коливалася від 5,7\% до 68,2\%, у пухлинах - від 9,88\% до 23,08\%. Штами P. agglomerans, виділені із ендофітного середовища винограду і пухлин, характеризувалися однаковими морфологічними, культуральними, тінкторіальними, фізіологічними властивостями. Незначні відмінності спостерігалися у здатності до утилізації вуглеводів. Штами Раntoеа із пухлин не спожсивали иукрозу і 25,0\% утилізували раффінозу в аеробних умовах, на відміну від штамів із неушкодженої лози. Жирнокислотний спектр був представлений жирними кислотами, що містять у ланиюзі від 12 до 19 атомів вуглеию. За жирнокислотним складом вісімнадцать штамів були ідентифіковані як P. agglomerans-GC subgroup A. Для досліджуваних итамів домінантними в профілі є C16:0, C12:0, C14:0, C17:0 cyclow7c. Виділені штами P. agglomerans не проявили антагоністичної активності щзоо колекиійних штамів E. carotovora, A. tumefaciens $i$ A. vitis. Висновки. Кількісний склад мікробіоти ендофітного середовища лози і пухлин був неоднаковим i залежав від джерела виділення, погодних умов і сорту винограду. Штами P. agglomerans, виділені із лози і пухлин, характеризувалися однаковими біологічними ознаками, за виключенням здатності до утилізації окремих
\end{abstract}


вуглеводів. Жирнокислотний склад досліджених итамів Рапtoеа був представлений жирними кислотами з 12-19 атомів вуглещњю у ланџюзі. Антагоністичної активності до колекиійних штамів E. carotovora, A. tumefaciens i A. vitis не виявлено.

Ключові слова:Pantoea agglomerans, ендофітне середовище виноградної лози і пухлин, чисельність, біологічні властивості.

Т. В. Иваница, И. В. Страшнова

Одесский национальный университет имени И. И. Мечникова, ул. Дворянская, 2, Одесса, 65082, Украина, тел.: +38 (0482) 6879 64, e-mail: t.ivanytsia@gmail.com

\section{ЧИСЛЕННОСТЬ И БИОЛОГИЧЕСКИЕ СВОЙСТВА БАКТЕРИЙ РANTOEA AGGLOMERANS, ВЫДЕЛЕННЫХ ИЗ РАЗНЫХ СОРТОВ ВИНОГРАДА ОДЕССКОЙ ОБЛАСТИ}

Реферат

Цель. Изолировать и исследовать биологические свойства Pantoea agglomerans из внутренней среды винограда и опухолей, отобранных из виноградников Одесской области. Методы. Образиы виноградной лозы сортов "Аркадия», «Молдова» и «Одесский сувенир» и опухолей, срезанных с пораженной лозы этих сортов, предварительно стерилизовали, измельчали на фрагменты, вносили в колбы с дистиллированной водой и перемешивали в шейкере при $28{ }^{\circ} \mathrm{C}$ в течение 3 ч. Делали серию 10-ти кратных последовательных разведений и высевали на поверхность чашек Петри с питательной агаром. Инкубировали при $28^{\circ} \mathrm{C}$ в течение 24-48 часов. Проводили количественный учет, выделяли чистые культуры и исследовали их культуральные, морфологические, физиолого-биохимические свойства, определяли состав клеточных липидов и проводили идентификацию выделенных итаммов. Антагонистическую активность P. agglomerans определяли луночно-диффузным методом. Результаты. Численность бактерий во внутренней среде винограда колебалась в пределах 5,63 $\pm 1,3 X 10^{3} \mathrm{KOE} / \mathrm{cm}^{3}-2,96 \pm 1,3 X 10^{5}$

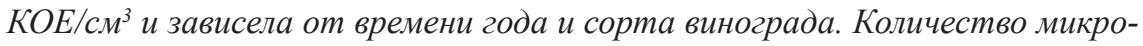
организмов в опухолях была больше чем в неповрежденной лозе в тот же период. Массовая доля P. agglomerans в лозе колебалась om 5,7\% до 68,2\%, в опухолях - от 9,88\% до 23,08\%. Штаммы P. agglomerans, вылеленные из эндофитной среды винограда и опухолей, характеризовались одинаковыми морфологическими, культуральньлми, тинкториальньми, физиологическими свойствами. Незначительные различия наблюдались в способности к утилизации углеводов. Штаммы Рапtоеа из опухолей не разлагали сахарозу и 25,0 \% утилизировали раффинозу в аэробных условиях, в отличие от штаммов с неповрежденной лозы. Жирнокислотньй спектр был представлен жирными кислотами, содержашими в иееи от 12 до 19 атомов углерода. По жирнокислотному составу восемнадиать штаммов были идентифицированы как P. agglomerans-GC subgroup А. Для исследуемых штаммов доминантными в профиле являются C16:0, C12:0, C14:0, C17:0 cyclo w7c. Выделенные штаммы P. agglomerans не проявили антагонистической активности в 
отношении коллекциионных штаммов E. carotovora, A. tumefaciens u A. vitis. Выводы. Количественный состав микробиоть эндофитной среды лозы и опухолей был неодинаковым и зависел от источника выделения, погодных условий и сорта винограда. Штаммы P. agglomerans, выделенные из лозы и опухолей, характеризовались одинаковыми биологическими признаками, за исключением способности к утилизации отдельных углеводов. Жирнокислотный состав исследованных штаммов Рапtоеа был представлен жирными кислотами с 12-19 атомами углерода в цеепи. Антагонистической активности к коллекционных итаммов E. carotovora, A. tumefaciens $u$ A. vitis не обнаружено.

Ключевые слова: Pantoea agglomerans, эндофитная среда виноградной лозы и опухолей, численность, биологические свойства.

\section{СПИСОК ВИКОРИСТАНОЇ ЛІТЕРАТУРИ}

1. Іваниия В. О., Горшкова О. Г., Коротаєва Н. В., Волювач О. В., Гудзенко T. B., Остапчук A. M. Склад жирних кислот ліпідів штаму Bacillus sp. О3-5, виділеного із забрудненого нафтою грунту о. Зміїний // Мікробіологія і біотехнологія. - 2015. - 32, № 4. - С. 28-36.

2. Нетрусов А. И., Егорова М. А., Захарчук Л. М., Колотилова Н. Н. и $\partial p$. Практикум по микробиологии: учебное пособие для студентов высших учебных заведений. - М.: Академия, 2005. - 608 с.

3. Andrews J. H., Harris R. F. The ecology and biogeography of microorganisms on plant surfaces. // Ann. Rev. Phytopathol. - 2000. - 38. - P. 145-180.

4. Brady C. L. Emended description of the genus Pantoea, description of four species from human clinical samples, Pantoea septica sp. nov., Pantoea eucrina sp. nov., Pantoea brenneri sp. Nov. and Pantoea conspicua sp. nov., and transfer of Pectobacterium cypripedii (Hori 1911) Brenner et al. 1973 emend. Hauben et al. 1998 to the genus as Pantoea cypripedii comb. nov. Int. // J. Syst. Evol. Microbiol. 2010. - 60. - P. 2430-2440.

5. Brady C. L., Cleenwerck I., Westhuizen L. V., Venter S. N., Coutinho T.A., \& Vos P.D. Pantoea rodasii sp. nov., Pantoea rwandensis sp. nov. and Pantoea wallisii sp. nov., isolated from Eucalyptus. // International Journal Of Systematic And Evolutionary Microbiology. - 2016. - 62. - P. 1457-1464.

6. Brady C.L. et al. Phylogeny and identification of Pantoea species associated with plants, humans and the natural environment based on multilocus sequence analysis (MLSA) // Syst. Appl. Microbiol. -2008. - 31. - P. 447-460.

7. Costa E., Teixidó N., Usall J., Atarés E., Viñas I. Production of the biocontrol agent Pantoea agglomerans strain CPA -2 using commercial products and by-products. // Appl. Microbiol. Biotechnol. - 2001. 56 - P. 367-371.

8. Cruz A.T., Cazacu A.C., Allen C.H. Pantoea agglomerans: a plant pathogen causing human disease. // J. Clin. Microbiol. - 2007. - 45:6. - P. 1989-1992.

9. Dutkiewicz J., Mackiewicz B., Kinga Lemieszek M., Golec M., Milanowski J. Pantoea agglomerans: a mysterious bacterium of evil and good: Part III. Deleterious effects: infections of humans, animals and plants. Ann. Agric. Environ. Med. // 2016. - 23:2. - P. 197-205.

10. Dutkiewicz J, Mackiewicz B, Kinga Lemieszek M, Golec M, Milanowski J. 
Pantoea agglomerans: a mysterious bacterium of evil and good: Part IV. Beneficial effects. // Ann. Agric. Environ. Med. -2016.- 23 :2.-P. 206-222.

11. Dutkiewicz J., Mackiewicz B., Kinga Lemieszek M., Golec M. \& Milanowski J. Pantoea agglomerans: a mysterious bacterium of evil and good. Part III. Deleterious effects: infections of humans, animals and plants. // Ann. Agric. Environ. Med. - 2016. - 23. - P. 197-205 .

12. Gavini F., Mergaert J., Beji A., Mielcarek C., Izard D., Kersters K., De Ley J. Transfer of Enterobacter agglomerans (Beijerinck 1888) Ewing and Fife 1972 to Pantoea gen. nov. as Pantoea agglomerans comb. nov. and description of Pantoea dispersa sp. nov. Int. // J. Syst. Bacteriol. 1989. - 39:3. - P. 337-345.

13. Kato Tanaka Y. et al. Pantoea theicola sp. nov., isolated from black tea. // Int. J. Syst. Evol. Microbiol. - 2015. - 65. - P. 3313-3319.

14. Lim J.A., Lee D.H., Kim B.Y. \& Heu S. Draft genome sequence of Pantoea agglomerans $\mathrm{R} 190$, a producer of antibiotics against phytopathogens and foodborne pathogens. // J. Biotechnol. - 2014. - 188. - P. 7-8.

15. Mishra A., Chauhan P. S., Chaudhry V., Tripathi M. \& Nautiyal C. S. Rhizosphere competent Pantoea agglomerans enhances maize (Zea mays) and chickpea (Cicer arietinum L.) growth, without altering the rhizosphere functional diversity. Anton. Leeuw. // Int. J. G.2011. - 100. - P. 405-413.

16. J. Mergaert, L. V. UGent, K. Kersters Transfer of Erwinia-ananas (synonym, Erwinia-uredovora) and Erwinia-stewartii to the genus Pantoea emend as Pantoea-ananas (serrano 1928) comb-nov and Pantoea-stewartii (smith 1898) comb-nov, respectively, and description of Pantoea-stewartii subsp indologenes subsp nov. // Int. J. Syst. Bacteriol.1993. - 43. -P. 162-173.

17. Popp A., Cleenwerck I., Iversen C., De Vos P. \& Stephan R. Pantoea gaviniae sp. nov. and Pantoea calida sp. nov., isolated from infant formula and an infant formula production environment. // Int. J. Syst. Evol. Microbiol.2010. - 60. - P. 2786-2792.

18. Rezzonico F., Smits T.H.M., Montesinos E., Frey J.E., Duffy B. Genotypic comparison of Pantoea agglomerans plant and clinical strains. // BMC Microbiology. - 2009. - 9. -P. 204.

19. Sturz A.V., Christie B.R., Nowak J. Bacterial endophytes: potential role in developing sustainable systems of crop production. // Critical Reviews in Plant Science. 2000. - 19. - P. 1-30.

\section{References}

1. Ivanytsia VO, Gorshkova OG, Korotaieva NV, Voluvach OV, Gudzenko TV, Ostapchuk AM. The composition of fatty acids of strain Bacillus sp. OZ-5, isolated from oil contaminated groud from Zmiiniy island. // Mikrobiologiia I biotechnologiia. 2015; 32(4): 28-36. (in Ukrainian)

2. Netrusov AI, Egorova MA, Zaharchuk LM, Kolotilova NN Microbiology of work shop: Textbook for higher education institutions. // Moscow: Akademiya, 2005. 608.(in Russian)

3. Andrews JH, Harris RF. The ecology and biogeography of microorganisms on plant surfaces. Ann. Rev. Phytopathol. 2000; 38:145-180.

4. Brady C L. Emended description of the genus Pantoea, description of four 
species from human clinical samples, Pantoeaseptica sp. nov., Pantoeaeucrina sp. nov., Pantoeabrenneri sp. Nov. and Pantoeaconspicua sp. nov., and transfer of Pectobacteriumcypripedii (Hori 1911) Brenner et al. 1973 emend. Hauben et al. 1998 to the genus as Pantoeacypripedii comb. nov. Int. J. Syst. Evol. Microbiol. 2010; 60: 2430-2440.

5. Brady CL, Cleenwerck I, Westhuizen, LV, Venter, SN, Coutinho TA, Vos P D. Pantoea rodasii sp. nov., Pantoea rwandensis sp. nov. and Pantoea wallisii sp. nov., isolated from Eucalyptus. International Journal Of Systematic And Evolutionary Microbiology. 2016; 62:1457-1464.

6. Brady CL. Phylogeny and identification of Pantoea species associated with plants, humans and the natural environment based on multilocus sequence analysis (MLSA). Syst. Appl. Microbiol.2008; 31: 447-460.

7. Costa E, Teixidó N, Usall J, Atarés E, Viñas I. Production of the biocontrol agent Pantoea agglomerans strain CPA -2 using commercial products and byproducts. Appl. Microbiol. Biotechnol. 2001; 56: 367-371.

8. Cruz AT, Cazacu AC, Allen CH. Pantoea agglomerans: a plant pathogen causing human disease. J. Clin. Microbiol. 2007;45(6): 1989-1992.

9. Dutkiewicz J, Mackiewicz B, Kinga Lemieszek M, Golec M, Milanowski J. Pantoea agglomerans: a mysterious bacterium of evil and good: Part III. Deleterious effects: infections of humans, animals and plants. Ann. Agric. Environ. Med. 2016; 23 (2): 197-205.

10. Dutkiewicz J, Mackiewicz B, Kinga Lemieszek M, Golec M, Milanowski J. Pantoea agglomerans: a mysterious bacterium of evil and good: Part IV. Beneficial effects. Ann. Agric. Environ. Med. 2016; 23 (2): 206-222.

11. Dutkiewicz J, Mackiewicz B, Kinga Lemiesze, M, Golec, M Milanowski J. Pantoea gglomerans: a mysterious bacterium of evil and good. Part III. Deleterious effects: infections of humans, animals and plants. Ann. Agric. Environ. Med. 2016; 23: 197-205 .

12. Gavini F, Mergaert J, Beji A, Mielcarek C, Izard D, Kersters K, De Ley J. Transfer of Enterobacter agglomerans (Beijerinck 1888)Ewing and Fife 1972 to Pantoea gen. nov. as Pantoea agglomerans comb. nov. and description of Pantoea dispersa sp. nov. Int. J. Syst. Bacteriol.1989; 39 (3): 337-345.

13. Kato Tanaka, Y. Pantoea theicola sp. nov., isolated from black tea. Int. J. Syst. Evol. Microbiol. 2015; 65: 3313-3319.

14. Lim, JA, Lee DH, Kim BY, Heu S. Draft genome sequence of Pantoea agglomerans $\mathrm{R} 190$, a producer of antibiotics against phytopathogens and foodborne pathogens. J. Biotechnol.2014; 188: 7-8.

15. Mishra A, Chauhan PS, Chaudhry V, Tripathi M, Nautiyal CS Rhizosphere competent Pantoea agglomerans enhances maize (Zea mays) and chickpea (Cicer arietinum L.) growth, without altering the rhizosphere functional diversity. Anton. Leeuw. Int. J. G. 2011; 100: 405-413.

16. Mergaert J, UGent LV, Kersters $K$. Transfer of Erwinia-ananas (synonym, Erwinia-uredovora) and Erwinia-stewartii to the genus Pantoea emend as Pantoeaananas (serrano 1928) comb-nov and Pantoea-stewartii (smith 1898) comb-nov, respectively, and description of Pantoea-stewartii subsp indologenes subsp nov. Int. J. Syst. Bacteriol. 1993; 43: 162-173. 
17. Popp A, Cleenwerck I, Iversen C, De Vos P, Stephan R. Pantoea gaviniae sp. nov. and Pantoea calida sp. nov., isolated from infant formula and an infant formula production environment. Int. J. Syst. Evol. Microbiol. 2010; 60: 27862792.

18. Rezzonico F, Smits THM, Montesinos E, Frey JE, Duffy B. Genotypic comparison of Pantoea agglomerans plant and clinical strains. BMC Microbiology. 2009; 9: 204.

19. Sturz AV, Christie BR, Nowak J. Bacterial endophytes: potential role in developing sustainable systems of crop production. Critical Reviews in Plant Science. 2000; 19: 1-30.

Стаття надійшла до редакції 20.08.2018 p. 